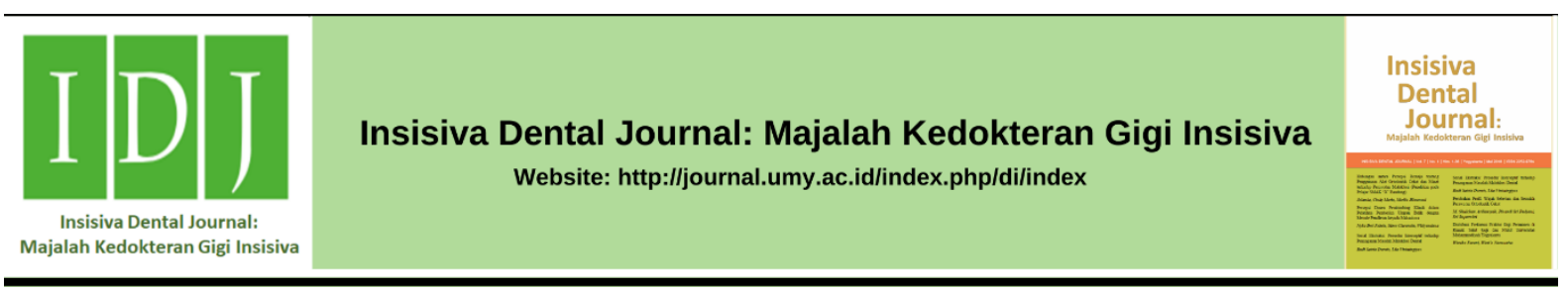

Research Article

\title{
Pengaruh Daya Anti Bakteri Ekstrak Bunga Mawar Merah (Rosa damascena Mill) Terhadap Pertumbuhan Enterococcus faecalis
}

The Antibacterial Effect of Red Rose Extract (Rosa damascena Mill) on the Growth of Enterococcus faecalis

Yusrini Pasril ${ }^{1, *}$, Dita Okasari

${ }^{1}$ Departemen Konservasi Gigi, Program Studi Kedokteran Gigi, Fakultas Kedokteran dan Ilmu Kesehatan, Universitas Muhammadiyah Yogyakarta, Jalan Brawijaya, Tamantirto, Kasihan, Bantul, Indonesia.

${ }^{2}$ Program Studi Kedokteran Gigi, Fakultas Kedokteran dan Ilmu Kesehatan, Universitas Muhammadiyah Yogyakarta, Jalan Brawijaya, Tamantirto, Kasihan, Bantul, Indonesia.

Received date: February $7^{\text {th }}, 2020$; reviewed date: March $18^{\text {th }}, 2020$ revised date: May $1^{\text {st }}, 2020$; accepted date: May $21^{\text {st }}, 2020$ DOI : $10.18196 /$ di. 9114

\begin{abstract}
Abstrak
Ekstrak bunga mawar merah (Rosa damascena Mill) mengandung tannin, geraniol, nerol, citronellol, flavonoid yang memiliki efek antibakteri. Enterococcus faecalis mampu bertahan hidup pada lingkungan dengan pH tinggi dan bertahan dalam saluran akar yang bisa menginvasi tubuli dentin. Agen antibakteri tersebut menghambat bakteri dengan mengganggu aktivitas transpeptidase peptidoglikan sehingga pembentukan dinding sel terganggu dan sel mengalami lisis. Penelitian ini bertujuan untuk mengetahui daya antibakteri ekstrak bunga mawar merah (Rosa damascena Mill) terhadap pertumbuhan Enterococcus faecalis. Penelitian ini merupakan penelitian eksperimental laboratorium In Vitro. Konsentrasi ekstrak bunga mawar merah (Rosa damascena Mill) yang digunakan yaitu $25 \%, 50 \%, 75 \%$, dan $100 \%$. Kalsium hidroksida $\mathrm{Ca}(\mathrm{OH}) 2$ digunakan sebagai kontrol positif dan aquades digunakan sebagai kontrol negatif. Uji daya anti bakteri menggunakan metode difusi sumuran pada cawan petri selama 24 jam dengan suhu inkubasi $37^{\circ} \mathrm{C}$. Pengaruh daya anti bakteri ekstrak bunga mawar merah (Rosa damascena Mill) diketahui melalui uji Kruskal Wallis. Hasil penelitian didapatkan rata-rata zona radikal yang terbentuk pada ekstrak bunga mawar merah (Rosa damascena Mill) dengan konsentrasi 25\% sebesar 4,048 mm, konsentrasi 50\% sebesar 5,165 mm, konsentrasi 75\% sebesar 6,185 mm, konsentrasi 100\% sebesar 8,895 mm, dan pada kontrol positif sebesar 5,5 mm. Dapat disimpulkan bahwa ekstrak bunga mawar merah (Rosa damascena Mill) memiliki pengaruh daya antibakteri terhadap pertumbuhan Enterococcus faecalis dan konsentrasi terbaik yaitu $100 \%$.
\end{abstract}

Kata Kunci: Bakteri Enterococcus faecalis; Ekstrak bunga mawar merah; Rosa damascena Mill; Metode difusi

\begin{abstract}
Red rose extract (Rosa damascena Mill) contains tannin, geraniol, nerol, citronellol, flavonoids, which have antibacterial effects. Enterococcus faecalis is able to survive in high $\mathrm{pH}$ environments and survive in root canals that can invade dentinal tubules. These antibacterial agents inhibit bacteria by interfering with the activity of peptidoglycan transpeptidase so that cell wall formation is disrupted and cells undergo lysis. This study aims to determine the antibacterial power of red rose extract (Rosa damascena Mill) on the growth of Enterococcus faecalis. This research is an experimental study of In Vitro laboratory. The concentration of red rose extract (Rosa damascena Mill) used is 25\%, 50\%, 75\%, and 100\%. Calcium hydroxide Ca(OH)2 is used as a positive control, and aquades is used as a negative control. Antibacterial power test uses the method of diffusion of wells on Petri dishes for 24 hours with an incubation temperature of $37^{\circ}$ C. The effect of the antibacterial power of red rose (Rosa damascena Mill) extract was known through the Kruskal Wallis test. The results showed an average radical zone formed in red rose extract (Rosa damascena Mill) with a concentration of $25 \%$ by $4.048 \mathrm{~mm}$, a concentration of $50 \%$ by $5.165 \mathrm{~mm}$, a concentration of $75 \%$ by $6.185 \mathrm{~mm}$, a concentration of $100 \%$ by $8.895 \mathrm{~mm}$, and at a positive control of $5.5 \mathrm{~mm}$. It can be concluded that the extract of a red rose (Rosa damascena Mill) has the effect of antibacterial power on the growth of Enterococcus faecalis, and the best concentration is 100\%.
\end{abstract}

Keywords: Enterococcus faecalis bacteria; Red rose extract; Rosa damascena Mill; Diffusion method

* Corresponding author, e-mail: yusrinipasril@yahoo.com 


\section{PENDAHULUAN}

Kesehatan gigi dan mulut adalah hal yang sangat penting untuk diperhatikan karena gigi dan mulut merupakan pintu gerbang untuk masuknya bakteri dan kuman ke dalam tubuh. Menurut Riset Kesehatan Dasar tahun 2018, presentase penduduk Indonesia yang memiliki masalah kesehatan gigi dan mulut yaitu $57,6 \%$ dan masalah terbesar di Indonesia yaitu gigi berlubang, gigi rusak, atau sakit dengan presentase $45,3 \%$. Kerusakan gigi yang tidak dilakukan perawatan dapat menyebabkan gigi nekrosis atau kematian pada pulpa. Gigi yang sudah nekrosis dapat dipertahankan dengan perawatan saluran akar. $^{1}$

Perawatan saluran akar ada tiga tahap (triad endodontic) antara lain preparasi biomekanis, sterilisasi saluran akar, dan pengisian saluran akar (obturasi). ${ }^{2}$ Preparasi biomekanis terdiri dari pembersihan dan pembentukan saluran akar. Tujuan dari pembersihan saluran akar atau debridemen yaitu untuk membuang iritan dari saluran akar. Sterilisasi meliputi irigasi dan disinfeksi saluran akar. Obturasi atau pengisian saluran akar menggunakan bahan gutta percha yang bertujuan untuk menutup saluran akar secara tiga dimensi dari kamar pulpa sampai apeks. ${ }^{3}$

Enterococcus faecalis merupakan bakteri gram positif yang berbentuk ovoid. Bakteri ini bersifat fakultatif anaerob yang dapat hidup dan berkembang biak dengan oksigen maupun tanpa oksigen. Bakteri Enterococcus faecalis mampu bertahan hidup pada lingkungan dengan $\mathrm{pH}$ tinggi dan bertahan dalam saluran akar yang bisa menginvasi tubuli dentin yang menyebabkan bakteri Enterococcus faecalis menjadi bakteri patogen dan menyebabkan kegagalan perawatan saluran akar. Enterococcus faecalis lebih banyak ditemukan pada infeksi sekunder dibandingkan dengan infeksi primer. ${ }^{4}$ Infeksi sekunder yaitu infeksi pada saluran akar yang telah dilakukan perawatan saluran akar. Setiap kegagalan perawatan saluran akar selalu ada hubungannya dengan Enterococcus faecalis. ${ }^{5}$

Ekstrak bunga mawar merah (Rosa damascena Mill) mengandung tannin, geraniol, nerol, citronellol, flavonoid yang memiliki efek antibakteri. Flavonoid merupakan agen antibakteri yang melawan berbagai mikroorganisme patogen. Senyawa lain pada ekstrak bunga mawar merah (Rosa damascena Mill) yaitu tannin. Tannin mampu mengkerutkan dinding sel atau membran sel sehingga mengganggu permeabilitas sel itu sendiri.

Penelitian sebelumnya tentang "Efektivitas Ekstrak Kelopak Mawar Merah (Rosa damascena) terhadap Jamur Candida albicans" dengan konsentrasi ekstrak 12,5\%, 25\%, 50\%, dan 100\% diketahui mempunyai daya hambat terhadap pertumbuhan Candida albicans dan konsentrasi hambat minimum ekstrak kelopak mawar merah terhadap pertumbuhan Candida albicans adalah pada konsentrasi $100 \% .^{6}$ Penelitian tentang "Antibacterial and Antifungal Activity of Rosa damascena Mill Essential Oil, Different Extracts of Rose Petals" oleh Shohayeb (2014) ${ }^{7}$ untuk menilai aktivitas antimikroba pada ekstrak Rosa damascena Mill dengan pelarut yang berbeda secara kuantitatif terhadap 3 jenis jamur (Penicillium notatum, Aspergillus niger dan Candida albicans), bakteri gram positif, dan bakteri gram negatif. Hasil yang didapatkan yaitu bakteri gram positif (Staphylococcus aureus, Bacillus subtilis dan Streptococcus pyogenes) lebih sensitif dibandingkan dengan bakteri gram negatif. ${ }^{7}$

Penelitian ini bertujuan untuk mengetahui daya antibakteri ekstrak bunga mawar merah (Rosa damascena Mill) terhadap pertumbuhan Enterococcus faecalis.

\section{MATERIAL DAN METODE}

Penelitian ini menggunakan desain eksperimental laboratorium in vitro. Pembuatan ekstrak bunga mawar merah (Rosa damascena Mill) dilakukan di Laboratorium Farmasi FKIK Universitas 
Muhammadiyah Yogyakarta dan pengujian daya antibakteri dilakukan di Laboratorium Mikrobiologi FKIK Universitas Muhammadiyah Yogyakarta. Variabel pengaruh yang digunakan yaitu ekstrak bunga mawar merah (Rosa damascena Mill) dengan konsentrasi 25\%, 50\%, 75\%, $100 \%$, dan kalsium hidroksida sebagai kontrol positif, serta aquades steril sebagai kontrol negatif. Variabel terpengaruh yang digunakan yaitu Enterococcus faecalis.

Langkah pertama yang dilakukan yaitu membuat ekstrak bunga mawar merah (Rosa damascena Mill) dengan metode maserasi. Kemudian membuat suspense Enterococcus faecalis dengan cara mengambil satu ose Enterococcus faecalis menggunakan ose steril lalu dimasukkan ke dalam BHI dan kemudian diinkubasi selama 24 jam. Selanjutnya, memasukkan kapas lidi steril ke dalam suspensi bakteri lalu mengoleskan pada permukaan media pada setiap cawan petri; dan melakukan sumuran pada setiap cawan petri dengan diameter $5 \mathrm{~mm}$ dan kedalaman $5 \mathrm{~mm}$. Uji daya antibakteri menggunakan metode difusi. Ekstrak bunga mawar merah (Rosa damascena Mill) dengan konsentrasi yang berbeda diteteskan ke dalam lubang sumuran menggunakan pipet tetes sebanyak 2-3 tetes. Kemudian masukkan cawan petri ke inkubator selama 24 jam pada suhu $37^{\circ} \mathrm{C}$. Untuk mengukur zona radikal digunakan sliding caliper. Selanjutnya pengaruh daya anti bakteri ekstrak bunga mawar merah (Rosa damascena Mill) diketahui melalui uji Kruskal Wallis.

\section{HASIL}

Tabel 1 merupakan hasil pengukuran diameter zona radikal dengan enam kali pengulangan pada ekstrak $25 \%$, $50 \%, 75 \%$, 100\%, kalsium hidroksida sebagai kontrol positif dan aquades sebagai kontrol negatif. Hasil rata-rata diameter zona radikal pada ekstrak $25 \%$ yaitu 4,048 $\mathrm{mm}$, rata-rata diameter zona radikal pada ekstrak $50 \%$ yaitu $5,165 \mathrm{~mm}$, rata-rata diameter zona radikal pada ekstrak $75 \%$ yaitu $6,185 \mathrm{~mm}$, rata-rata diameter zona radikal pada ekstrak $100 \%$ yaitu $8,895 \mathrm{~mm}$. Rata-rata diameter zona radikal pada kalsium hidroksida sebesar 5,5 $\mathrm{mm}$ dan rata-rata tersebut lebih rendah dibandingkan dengan rata-rata diameter zona radikal pada ekstrak $75 \%$ dan ekstrak $100 \%$. Rata-rata diameter zona radikal pada kalsium hidroksida lebih tinggi dibandingkan dengan rata-rata diameter zona radikal ekstrak 25\% dan ekstrak 50\%.

Hasil uji normalitas Shapiro Wilk (jumlah sampel< 50) menunjukkan bahwa data tidak terdistribusi normal karena nilai signifikan $\mathrm{P}<0,05$ yaitu pada kalsium hidroksida memiliki nilai signifikan 0,031 . Hal ini disebabkan karena zona radikal kalsium hidroksida pada perlakuan pertama memiliki rata-rata 7,28 mm. Pada ekstrak $25 \%$ memiliki nilai signifikan 0,665 , ekstrak $50 \%$ memiliki nilai signifikan 0,467, ekstrak $75 \%$ memiliki nilai signifikan 0,897 dan ekstrak $100 \%$ memiliki nilai signifikan 0,131 .

Tabel 2 menunjukkan bahwa nilai $\mathrm{p}=0,000$ atau nilai $(\mathrm{p})<0,05$ sehingga $\mathrm{H} 0$ ditolak yaitu terdapat perbedaan yang signifikan antara kelompok perlakuan yang satu dengan kelompok perlakuan yang lainnya. Semakin tinggi konsentrasi ekstrak bunga mawar merah (Rosa damascena Mill), maka semakin besar diameter zona radikal.

Tabel 1. Hasil Pengukuran Diameter Zona Radikal

\begin{tabular}{ccccccc}
\hline \multicolumn{6}{c}{ Zona Radikal (mm) } \\
\hline \multirow{2}{*}{$\begin{array}{c}\text { Cawan } \\
\text { Petri }\end{array}$} & $25 \%$ & $50 \%$ & $75 \%$ & $100 \%$ & $\mathrm{Ca}(\mathrm{OH}) 2$ & Aquades \\
\cline { 2 - 6 } & & & & & \\
\hline 1 & 3,21 & 5,21 & 6 & 9,25 & 7,28 & 0 \\
2 & 3,58 & 5,58 & 6,33 & 7,93 & 5,2 & 0 \\
3 & 4,11 & 5,18 & 6,48 & 9,18 & 5,5 & 0 \\
4 & 4,33 & 5,1 & 5,85 & 9,43 & 4,7 & 0 \\
5 & 4,33 & 5,16 & 6,3 & 9,15 & 5,06 & 0 \\
6 & 4,73 & 4,76 & 6,15 & 8,43 & 5,26 & 0 \\
Rerata & 4,048 & 5,165 & 6,185 & 8,895 & 5,5 & 0 \\
\hline
\end{tabular}

Tabel 2. Uji Non Parametrik Kruskal Wallis Zona Radikal

\begin{tabular}{ccc}
\hline Chi-Square & Df & Asymp. Sig \\
\hline 25,094 & 4 &, 000 \\
\hline
\end{tabular}




\section{PEMBAHASAN}

Hasil penelitian menunjukkan bahwa terdapat daya antibakteri pada ekstrak bunga mawar merah (Rosa damascena Mill) terhadap pertumbuhan Enterococcus faecalis yang dibuktikan dengan adanya zona radikal pada cawan petri. Dari analisis data tersebut, kelompok yang memiliki daya antibakteri paling tinggi yaitu pada kelompok ekstrak 100\% dan kelompok yang memiliki daya antibakteri paling rendah yaitu pada kelompok ekstrak 25\%. Hasil uji non parametrik Kruskal Wallis memiliki nilai signifikan sebesar $0,000(\mathrm{p}<0,05)$ yang berarti bahwa kelompok perlakuan yang satu dengan kelompok perlakuan yang lainnya memiliki perbedaan yang signifikan.

Enterococcus faecalis menyebabkan infeksi endodontik dan berperan dalam peradangan periradikular karena faktor virulensinya. ${ }^{8}$ Enterococcus faecalis dapat menempel pada dinding saluran akar, berkumpul, dan membentuk komunitas pada biofilm yang memungkinkan bakteri menjadi 1000 kali lebih tahan terhadap fagositosis, antibodi, dan antimikroba dari organisme yang tidak memproduksi biofilm. ${ }^{9}$ Zat agregasi, karbohidrat, dan gugus pengikat fibronektin akan memfasilitasiperlekatan organisme ke kolagen tipe I dan protein matrik ekstraseluler berada pada dentin. ${ }^{10}$

Flavonoid adalah senyawa polifenolik yang diproduksi sebagai metabolit sekunder dari tanaman. ${ }^{11}$ Kelompok flavonoid yang umum adalah difenilpropana yang memiliki satu atau lebih gugus fenolik. ${ }^{12}$ Flavonoid merupakan agen antibakteri yang melawan berbagai mikroorganisme patogen. Flavonoid memiliki kemampuan yang komplek dengan protein ekstraseluler yang mengganggu membran bakteri dan merusak dinding sel bakteri. ${ }^{13}$

Senyawa lain pada ekstrak bunga mawar merah (Rosa damascena Mill) yaitu tannin. ${ }^{14}$ Tannin mampu mengkerutkan dinding sel atau membran sel sehingga mengganggu permeabilitas sel itu sendiri. Akibatnya sel tidak dapat beraktivitas sehingga pertumbuhannya terhambat atau mati. Efek antibakteri tannin antara lain melalui reaksi dengan membran sel, inaktivasi enzim, dan destruksi fungsi materi genetik. ${ }^{15}$

\section{KESIMPULAN}

Berdasarkan hasil penelitian, dapat disimpulkan bahwa ekstrak bunga mawar merah (Rosa damascena Mill) dengan konsentrasi 25\%, 50\%, 75\%, dan 100\% memiliki pengaruh daya antibakteri terhadap pertumbuhan Enterococcus faecalis. Semakin tinggi konsentrasi ekstrak bunga mawar merah (Rosa damascena Mill), maka semakin tinggi pula diameter zona radikal atau semakin besar daya antibakteri terhadap pertumbuhan Enterococcus faecalis.

\section{DAFTAR PUSTAKA}

1. Triharsa, S., \& Mulyawati, E. Perawatan Saluran Akar Satu Kunjungan Pada Pulpa Nekrosis Disertai Restorasi Mahkota Jaket Porselin Fusi Metal dengan Pasak Fiber Reinforced Composit (Kasus Gigi Insisivus Sentralis Kanan Maksila). Maj. kedokt. gigi Indones., 2013; 20(1): 71-77.

2. Bachtiar, Z. A. Perawatan Saluran Akar pada Gigi Permanen Anak dengan Bahan Gutta Percha. Jurnal PDGI, 2016; 65(2): 60-67.

3. Ariani, N. G. A., \& Hadriyanto, W. Perawatan Ulang Saluran Akar Insisivus Lateralis Kiri Maksila dengan Medikamen Kalsium HidroksidaChlorhexidine. Maj. kedokt. gigi Indones., 2013; 20(1): 52-57.

4. Nurdin, D., \& Satari, M. H. Peranan Enterococcus faecalis terhadap persistensi infeksi saluran akar. In Prosiding Dies Forum, 2011; 52: 6976).

5. Mallick, R., Mohanty, S., Behera, S., Sarangi, P., Nanda, S., \& Satapathy, S. K. (2014). Enterococcus faecalis: A 
resistant microbe in endodontics. Int $J$ Contemp Dent Med Rev, 2014; 2014 (Article ID 011114): 1-2.

6. Sudiarti, D., \& Hidayah, N. Efektivitas Ekstrak Kelopak Mawar Merah (Rosa Damascene) Terhadap Jamur Candida albicans. BIOSHELL, 2017; 5(1): 306312.

7. Shohayeb, M., Abdel-Hameed, E. S. S., Bazaid, S. A., \& Maghrabi, I. Antibacterial and antifungal activity of Rosa damascena MILL. essential oil, different extracts of rose petals. Glob. J. Pharmacol., 2014; 8(1): 1-7.

8. Jain, H., Mulay, S., \& Mullany, P. Persistence of endodontic infection and Enterococcus faecalis: Role of horizontal gene transfer. Gene reports, 2016; 5(Dec): 112-116.

9. Kamaruzzaman, N. F., Tan, L. P., Mat Yazid, K. A., Saeed, S. I., Hamdan, R. H., Choong, S. S., ... \& Gibson, A. J. Targeting the bacterial protective armour; challenges and novel strategies in the treatment of microbial biofilm. Materials, 2018; 11(9): 1705.

10. Brodowska, K. M. Natural flavonoids: classification, potential role, and application of flavonoid analogues Eur. J. Biol. Res, 2017; 7(2): 108-123.

11. Arifin, B., \& Ibrahim, S. Struktur, bioaktivitas dan antioksidan flavonoid. Jurnal Zarah, 2018; 6(1): 21-29.

12. Das, A., \& Satyaprakash, K. Antimicrobial properties of natural products: A review. Pharma. Innov. J, 2018; 7: 532-537.

13. Ajizah, A. Sensitivitas Salmonella Typhimurium Terhadap Ekstrak Daun Psidium Guajava L. Bioscientiae, 2018; 1(1): 31-38.

14. Nayebi, N., Khalili, N., Kamalinejad, M., \& Emtiazy, M. A systematic review of the efficacy and safety of Rosa damascena Mill. with an overview on its phytopharmacological properties. Complement. Ther. Med., 2017; 34: 129-140.

15. Liu, M., Feng, M., Yang, K., Cao, Y., Zhang, J., Xu, J., ... \& Fan, M. Transcriptomic and metabolomic analyses reveal antibacterial mechanism of astringent persimmon tannin against Methicillin-resistant Staphylococcus aureus isolated from pork. Food Chem., 2020; 309: 125692. 